\title{
DEMOCRATIC PORTRAITURE: THE POLITICAL AESTHETICS OF THE INDIVIDUAL AND THE COLLECTIVE IN WHITMAN'S “SONG OF MYSELF”
}

\section{PAULO MILLER LOONIN}

In $A$ Thousand Plateaus, Gilles Deleuze and Felix Guattari polemicize, "We're tired of trees. We should stop believing in trees, roots, and radicles. They've made us suffer too much. . . . Many people have a tree growing in their heads, but the brain itself is much more a grass than a tree." Their hope for egalitarian rhizomatic grass as an alternative cultural form, one that might displace the hierarchical tree of tradition, continues to be appreciated today. I cite them, however, not to signal a theoretical orientation, but to suggest the enduring relevance of a problem Walt Whitman had previously figured, one that remains core to conversations about a just society. Anticipating Deleuze and Guattari by more than a century, Whitman championed a grassy ideal in 1855, using it as the namesake of his book Leaves of Grass and as a prominent figure in its flagship poem that he later titled "Song of Myself." Yet, while it is easy to see why the hierarchical tree is a problematic model for social formation, a question remains as to the wisdom of assuming, with Deleuze and Guattari-and apparently with Whitman - that grass would not make us suffer just as much. If trees are hegemonic, grass is a faceless interchangeable collection of pieces forming an impersonal aggregate, a field of grass, which might be wild, but can also be landscaped, mowed, and managed. In other words, grass shares many of the traits that make mass populations susceptible to authoritarian power. Trees figure order but at the cost of rigid hierarchy, while grass figures equality but at the potential cost of disorder or populist authoritarianism. While it has become common to describe Whitman as an extremist, he in fact handles this volatile figurative and political material carefully and deftly.

Whitman organizes "Song of Myself" around the tension between both the individual and the collective, seeking to recognize and harmonize these 
extremes, a persistent difficulty of democratic life. Following touchstone books by David S. Reynolds and Betsy Erkkila in the late 1980 s, ${ }^{2}$ much of Whitman scholarship has continued to concentrate on how Leaves of Grass engages the politics of antebellum American democracy and egalitarian ideals, even as that scholarship reframes itself according to various turns. ${ }^{3}$ Agreeing on the central importance of this topic to Whitman, ${ }^{4}$ critics differ on how he handles the tensions that arise between valorizing the individual and the collective. ${ }^{5}$ Does one come at the expense of the other? And what does the balance between the individual (the tree or blade of grass) and the collective (the field of grass) mean for the formation of egalitarian democratic politics? In the present essay, I engage this conversation through a misunderstood component of "Song of Myself": Whitman's deployment of democratic portraiture.

The influence of photography on "Song of Myself" is well known and photography indeed contributes much to the poem's formal and theoretical work. ${ }^{6}$ As is now established, Whitman departs from the commonly practiced method known as ekphrasis, where poems describe individual artworks. Heavily invested in the aesthetic and rhetorical potential of photographic and visual imagination flowering around him, Whitman takes the photographic portrait as an aesthetic model more than a poetic subject. ${ }^{7}$ As Alan Trachtenberg emphasizes, the famous 1855 Leaves of Grass frontispiece image of Whitman (see figure 1) "declares the method as well as the author of the book" (65). Ed Folsom even more explicitly states that Whitman "would not write about photography so much as he would write with and from photography" (Native Representations, 177). Building on such studies of Whitman and photography, I argue here that Whitman goes beyond drawing inspiration from photographic methods and applying them to poetry. Instead, he uses these methods as a starting point for his account of image-making as a reshaper of political regimes. In "Song of Myself," he extrapolates from photography to take portraiture in new directions and, finally, to push the limits of democratic formation as such. At issue in this conversation is a judgement about Whitman's aesthetic politics which critics have generally condemned in one way or another. I demonstrate that the political astuteness of his approach, however, has not been adequately recognized, particularly in his deployment of two distinct varieties of democratic portraiture: the mass-portrait and the portrait-series. Their dynamic counterbalance makes "Song of Myself" a more flexible, comprehensive, and politically sophisticated account of the relationship between self and society than the preponderance of scholarship credits. 


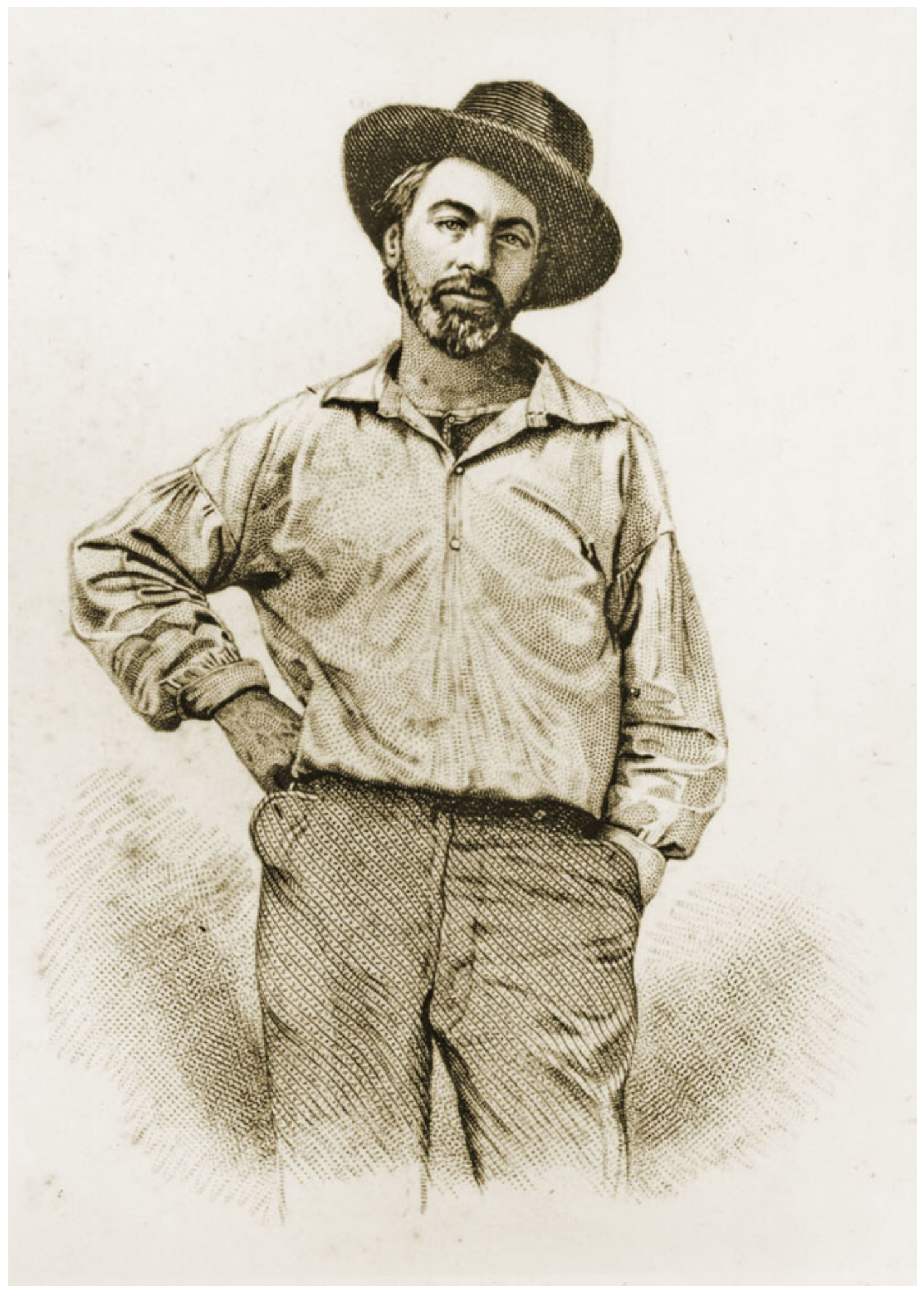

Figure 1. Samuel Hollyer engraving of a daguerreotype by Gabriel Harrison (original lost), "Street Figure," 1855. Steel Engraving. Frontispiece for Whitman's Leaves of Grass. 


\section{Democratic Portraiture and Whitman}

Deeper review of the criticism and cultural grounding for democratic portraiture, and the implications of photography (specifically, the shifting daguerreotype), will be brought back into discussion later. Here, I introduce the subject enough to begin a reading of "Song of Myself," since an understanding of some dimensions of this poem depends upon an understanding of democratic portraiture, my term for the mid-nineteenth-century practice whereby American authors tried to reconceptualize and re-use the traditionally elite genre of portraiture for democratic art and politics. In frontispieces, photographs, narratives, poems, and lectures, Whitman, along with others such as Frederick Douglass and Herman Melville, tested the ways a visual and/or verbal image of one unique self might fit together with images of other equal selves, forging egalitarian social-political forms. ${ }^{8}$ Whitman's democratic portraiture is rooted in alternation and counterpoise, the rhythm and flux of democratic life. The balanced structure of "Song of Myself" combines two aesthetic innovations corresponding to two modes of political formation: the mass-portrait corresponds to representative democracy and the portrait-series to radical democracy. As we shall see, they work together because the series contributes content and difference to the mass while the mass contributes form and unity to the series.

As Whitman was well aware, the portrait condenses expansive aesthetic, political, historical, and interpersonal matter into a tightly contained image. The etymology of "portrait" goes through French "pour trait," short for "trait pour trait": "feature for feature" or "line for line." implying an exact copying of person to picture, and something of that notion attaches to most discussions of the portrait. Addressing painted portraiture in the European tradition, Andreas Beyer states, "There is in fact no real theory of the portrait." ${ }^{\prime}$ Nevertheless, art history as a field naturally has its classifications and definitions. According to some art historical definitions of the portrait, which limit the category to pictures of actual named persons, the possibility of a democratic portrait should be ruled out from the start, since it implies either depicting individually or representing collectively many people - too many to be effectively recognized for their names, physical likenesses, and inner characters (traditional components of the portrait). Art historian James Breckenridge offers the following influential definition:

1) [A 'true' portrait] must represent a definite person, either living or of the past, with his distinctive human traits.

2) The person must be represented in such a manner that under no circumstances can his identity be confused with that of someone else. 
3) As a work of art, a portrait must render the personality, i.e., the inner individuality, of the person represented in his outer form. ${ }^{10}$

Given such constraints, philosopher and art historian Georges Didi-Huberman finds inherently contradictory "portraits of anonymous sitters, even of crowds, that portray the common people and thus defy representation." 11

However, to define as portraiture only such images as communicate the fully individuated identity of historical or contemporary persons is to rule out of bounds the most important questions associated with portraiture, broadly conceived, in the last two hundred years. The fact that democratic portraiture presents something of a paradox should not define it out of discussion but rather demand a consideration. To do justice to my subject, I try to approach such issues in the spirit of Whitman himself, who would find interest in considering what counts as a portrait, but who used the term loosely, granting the broadest possible conception for his own democratic purposes. This broad approach includes both visual and verbal modes of presenting images. ${ }^{12}$ For those disposed to enforce tightly controlled genre boundaries, then, it might be fairer to say that, under the name of "portraiture," this essay considers visual and verbal images of named and unnamed real and fictional persons and even personified forces in addition to portraits in the technical, art historical sense. The key idea I retain from traditional portraiture studies is the requirement of distinction/recognition, the rendering of a unique, specific individuality. It is the compounding of the democratic equality requirement with the traditional distinction/recognition requirement that makes the democratic portrait a volatile and revealing topos for modern representation.

The mass-portrait, one half of Whitman's democratic portraiture, hinges on the identification of one representative individual with the anonymous mass of population. It is the initial premise on which "Song of Myself" is built, the meaning of "what I assume you shall assume, / For every atom belonging to me as good belongs to you" (13). ${ }^{13}$ The speaker here "assumes" that what is true of "Walt Whitman, an American" (29) is true of all and any Americans. Essentially, the mass-portrait in "Song of Myself" is presented as a relationship of identity between the self-portrait of Whitman on the one hand, and crowds-often figured as grass and atoms-on the other. A second iteration of the same identificatory logic uses "I" and "You" as the paired figures of the mass-portrait. These two variations of the mass-portrait can be thought of schematically as "I-am-the-crowd" and "I-am-You." The apparently dual figure of the mass-portrait is in fact a proper portrait - a single image - because Whitman's claim is that the speaker is the crowd/grass/atoms, the speaker is the 
reader. They are not two identities but, seen clearly, they are one identity, one image-one comprehensive portrait. The danger of the mass-portrait, syntactically put, is unchecked hypotaxis, the subordination of one term to the other, self to crowd or crowd to self, I to you or you to I. ${ }^{14}$

The portrait-series, in contrast, is just that: a series of images. In "Song of Myself" the portrait-series is synonymous with the catalog sections. It is complementary to the mass-portrait and provides the vital diverse content that makes Whitman's assertions about the individual's identity with the whole more than a vacuous abstraction. The symbolically exhaustive stream of images in the poetic catalogs Whitman later denominated as sections 15 and 33 serve as a kind of proof that in the whole world nothing and no one escapes incorporation into the ecstatic I-am-the-crowd, I-am-you. The portrait-series is Whitman's answer to the riddle of how to integrate the one and the many: the progression of images of distinct persons are a middle ground version of grass and atoms, a middle ground version of the many, but not an identical/anonymous many. The catalogs present a horizontal, egalitarian many that still maintains difference and recognizability-one would not mistake "The duck-shooter walk[ing] by silent and cautious stretches" for "The spinning-girl retreat[ing] and advanc[ing] to the hum of the big wheel" (21) in the way that one would mistake two pieces of grass. The danger of this portrait-series strategy, syntactically put, is unchecked parataxis, the loss of a meaningful order to the flow of images. Late in life, Whitman confessed how this aspect of his portrait program could get out of hand when, looking upon the proliferation of photographs and engravings of himself, he commented that there were so many Whitmans he could not remember which he was. ${ }^{15}$ Thus, the portrait-series can potentially disperse identity rather than maintain it.

On its own, the mass-portrait - that is, representative democracy-tends to slide towards too much sameness and flatness (as when everyone is reduced to an anonymous atom or leaf of grass) or too much representativeness (as when everyone is reduced to Whitman's "I"). On its own, the portrait-series, or radical democracy, tends to slide towards incoherence and disintegration, an interminable list of images and interests with no clear relationship, reference, or meaning. "Song of Myself" is ordered so that the reader passes repeatedly in and out, back and forth, through segments emphasizing the mass-portrait and the portrait-series. The rewriting of hierarchies as equalities and dualities as unities is produced rhetorically by toggling between two modes of imaging democratic formation: the necessary order of the mass-portrait and the egalitarian value of the portrait-series. This is the democratic theory of the poem at work. 
Politically, the mass-portrait should especially be understood in terms of the substitution of The People - "the sign of democracy" and "a word en masse" (28-29) - for the royal Sovereign, which in prior political history occupied the role of legitimating the state and holding it together. The famous cover of Thomas Hobbes's Leviathan is a benchmark for this vision of the state: the giant figure of the King as Sovereign literally contains the myriad individuals residing within his power (see figure 2). As Hobbes explains, "A multitude of men, are made one person, when they are by one man, or one person, represented; so that it be done with the consent of every one of that multitude in particular."16 As Claude Lefort has shown, modern democratic states perform a rhetorical and real inversion whereby the fractious interests of discreet dependent subjects are reconceived as The People and substituted into the role of legitimating and ordering state power; they become the Sovereign symbolically. ${ }^{17}$ Whitman performs the same conversion in the mass-portrait. In the Preface to the 1855 Leaves he writes, "Did you suppose there could be only one Supreme? We affirm there can be unnumbered Supremes, and that one does not countervail another any more than one eyesight countervails another" (vii). Here Whitman expands the democratic claim to say that not only the collective People are Sovereign ("Supreme"), but that each individual person is also Sovereign. One trouble with this rhetorical claim is that if you try to visualize it as an embodied fact, or even a version of Hobbes' cover, it is virtually impossible, suggesting that the claim may struggle to gain purchase on actual states of affairs.

Nonetheless, Whitman compensates with an added trick in "Song of Myself," where the encompassing Sovereign figure alternates between The People and "Walt Whitman, an American." Like a hologram, a translucent palimpsest, or a daguerreotype that shifts with the angle of view, Whitman's "I," his self-portrait, is sometimes positioned as the omnipotent ruler-"I troop forth replenished with supreme power" (43) — and sometimes positioned as one of the small individual figures-"This is the city . . . and I am one of the citizens" (47). The variation affords Whitman his extravagant claims and his humble ruminations without contradiction: he is in both positions, by turns. Meanwhile, he continually provokes The People-his readers - to be their own Sovereign, their own Supreme. ${ }^{18}$

In seeing how democratic portraiture in the poem relates to democratic representation more broadly, I aim to shed light on the way scholars have talked about aesthetics and politics in Whitman's work. Many treat poetic form and political content as parallel but separate topics, along the lines of David Reynolds, who claims that Whitman "continued to explore the imaginative rather than the political possibilities of reform rhetoric, so that popular reform was chiefly 


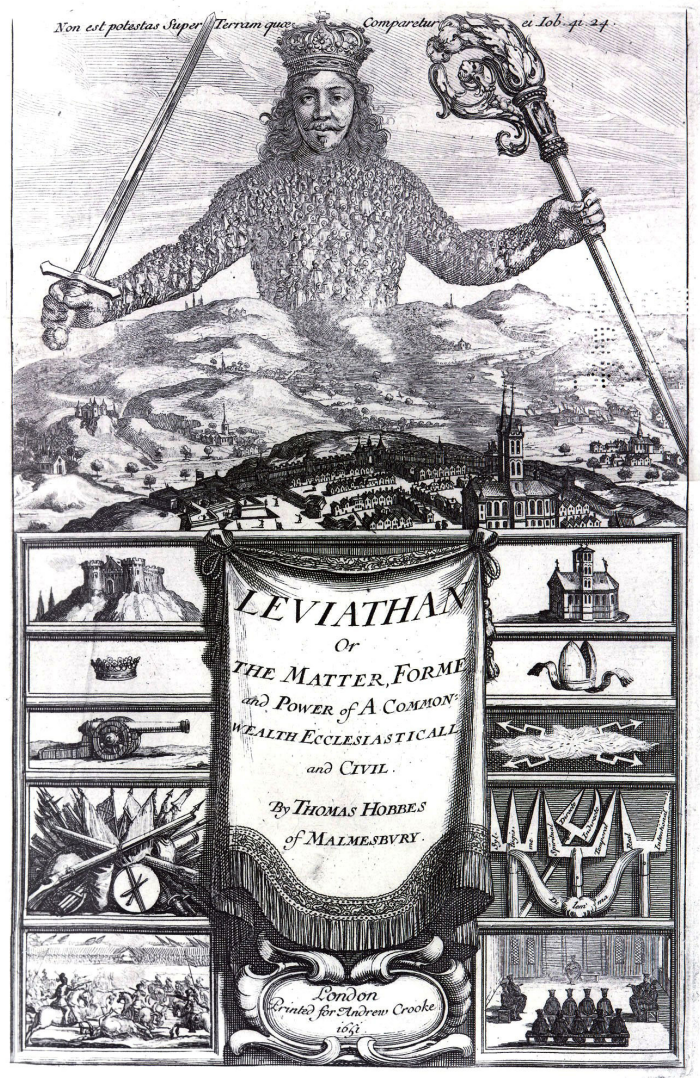

Figure 2. Abraham Bosse with creative input from Thomas Hobbes, 1651. Etching. Frontispiece for Hobbes's Leviathan. Below, details from the Bosse etching.

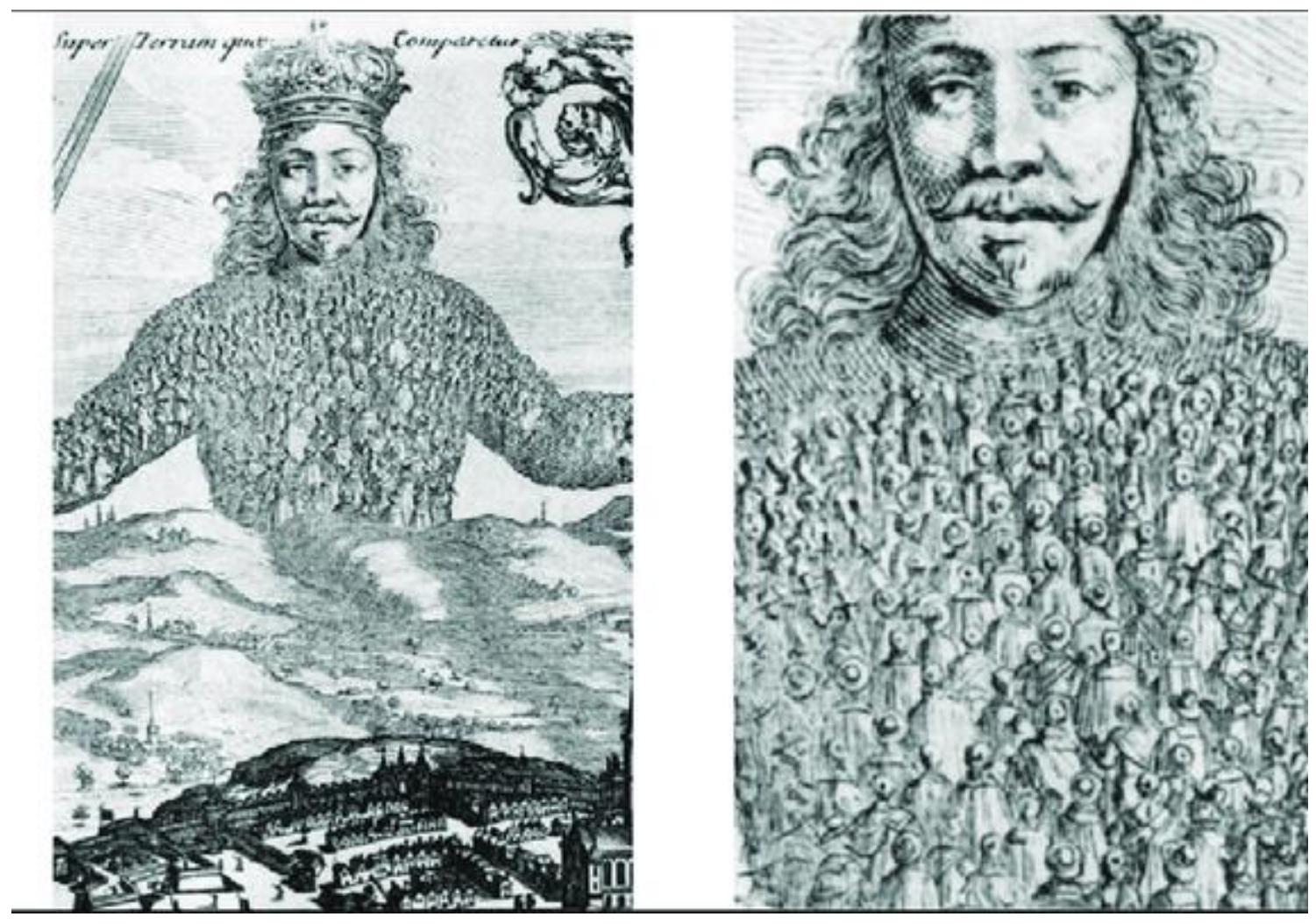


important as a training ground in zestful, defiant writing." 19 Here politics and style are two different worlds rubbing up against each other, and the interest of the politics lies chiefly in how it influences the style. Betsy Erkkila represents a shift to emphasizing political content as valuable in its own right: "The publication of Leaves of Grass in 1855," she writes, "was not an escape from politics but a continuation of politics by other means" (92). In helpfully recalibrating, however, Erkkila and her successors often veer towards relegating the style to a reflection of the politics. By contrast, I understand aesthetics and politics in "Song of Myself" not as two categories to be weighed against each other but as one formational question about how to imagine and represent a democratic ideal. The aesthetic is political; the political is aesthetic. "Song of Myself" challenges readers with new understandings of representation (literary and political) and representativeness (who is the representative hero of the American epic?), which aim precisely to merge aesthetic-political projects.

Reading portraiture in the poem brings all of these themes to life: Whitman's effort to represent and achieve equality, the relationship between literary and political representation, and the role played by photography and other visual arts in Whitman's poetry. By oscillating between the mass-portrait and the portrait-series, Whitman tried to imagine democracy in action while simultaneously enacting it in his poem. Here I show how far he pushed and what formal obstacles he encountered.

\section{The Mass in Mass-Portrait}

"Song of Myself" presents itself (indeed is itself ultimately named) as a self-portrait. In fact, the self-portrait is half of the mass-portrait, which has two parts: the self-portrait and the "en-masse" - the collective, the average, the crowd, the grass, the atoms, or the uniformity of Whitman's various catalogs. To the mass I now turn, since it is with the mass that Whitman lodges his claim to significance and relevance, his claim to making more than a personal self-indulgent bellow in "Song of Myself." As F. O. Matthiessen attests, "What saved Whitman from the last extreme of egotism was his insistence on the typical." ${ }^{20}$ His speaker speaks for more than himself; in the logic of the mass-portrait he speaks for everyone. And, in turn, the speaking self-portrait, the "I," draws validation and power from being one of the masses he speaks for and to. He depends on them for vitality and context.

"Song of Myself" rests in part on Whitman's ability to construct a plausible and inspiring presentation of the mass, seemingly an inauspiciously bland, 
abstract, uninspiring topic, even when Whitman applies an elevating adjective to it (as in "the divine average" referred to in the later poem, "Starting from Paumanock" ). If literature often relies on exemplarity-instances that are made to stand out - then the exemplary average is something of an oxymoron. A phrase of Whitman's indicative of the difficulty is "one of an average unending procession," which conveys the potential monotony of the material (43). In Democracy in America, Alexis de Tocqueville elaborates, "none of the single, nearly equal, roughly similar citizens of a democracy will do as a subject for poetry, but the nation itself calls for poetic treatment. The very likeness of individuals, which rules them out as subjects for poetry on their own, helps the poet to group them in imagination and make a coherent picture of the nation as a whole." 21 Replacing the classical or Romantic hero figure, the collective takes over as the locus of action, and this is supposed to provide the democratic poet with a suitable theme. How exactly an average mass becomes a compelling read is problematic. Later in life, Whitman would insist he had solved the problem: "I have imagined a life which should be that of the average man in average circumstances, and still grand, heroic" (quoted in Matthiessen, 650). To this end, Whitman's technique in the mass-portrait is to populate the space of the mass with a group of figures that are appealing to the imagination, although they are not precisely the stuff of classical or Romantic poetry.

The figure of grass is essential to imagining the average democratic En-Masse in "Song of Myself." Grass anchors the poem at beginning and end. We meet the speaker "observing a spear of summer grass" (13) and leave him "bequeath[ing] myself to the dirt to grow from the grass I love" (56). The book itself is composed of "leaves" of paper that bear obvious analogy to grass. Grass iterates like a refrain in what would become sections $1,5,6,9,17,31,33,39$, 49, and 52, and is inferred elsewhere throughout. Grass not only brackets and sustains but also generates the poem. According to Paul Zweig, "the entire poem will be an answer" to the question posed by the child, "What is the grass?"22 Similarly, for Folsom, the grass generates the poem repeatedly, once when the speaker "loafes" and observes "a spear of summer grass," 23 and, agreeing with Zweig, again in response to the child- "the answer to this [the child's] question will in some ways occupy the poet through all the rest of the sections" (24). Among many scholarly attempts to pin a genre designation on "Song of Myself," it is certainly, as Tony Tanner puts it, a "grasspoem," insofar as "the poem . . . organizes itself" around the grass. ${ }^{24}$

Beyond its general importance to the poem, how does the grass function in the mass-portrait? Identifying it with the "I," Whitman overlays his self-portrait 
with images of grass, as in, "I guess it must be the flag of my disposition, out of hopeful green stuff woven" (16). This overlay invites the reader, through the course of the poem, to toggle back and forth in imagination between Whitman as Whitman and Whitman as a nameless segment among the grass, that is, among the mass of citizens. The effect is a sort of blended portrait with elements of personality and elements of population. Whitman does political work through this blending, for, as Erkkila observes, "the poet reads in the hieroglyphic of the grass the politics of democracy. As the overarching figure of Leaves of Grass and the central image of 'Song of Myself,' the grass signifies many in one" (98). Such a thought lies behind the depiction of "the cow crunching with depressed head" (34) and the poet's question, "How is it I extract strength from the beef I eat?" (25). The grass is not only a political metaphor but also a material metonym, actually becoming part of the human body, eaten by the cow, which is then eaten by Whitman. For the circle to be complete, of course, the grass not only becomes the human but the human must become the grass, filtering into it through the soil after death. As he compensatorily puts it, "the grass is itself a child, the produced babe of the vegetation" (16). This is one of Whitman's versions of immortality, encapsulated in those closing lines, "I bequeath myself to the dirt to grow from the grass I love, / If you want me again look for me under your bootsoles" (56). Thus grass connects the mass-portrait with key themes of the poem including the nature of the self, part-whole relations, and immortality.

The poem's concern with immortality suggests that grass is not only a spatial but also a temporal figure. The spatial display is the single leaf amidst the field. The temporal dimension involves the circulation of atoms through the grass and the human both, so that each are composed of the same resilient and anonymous democratic substance. As Vivian Pollak elucidates, "Dying authenticates Whitman's claim, announced at the poem's inception, that 'Every atom belonging to me as good belongs to you.' Atomized into his component parts, he shares in a universalized, ungendered identity to which everyone and everything potentially belongs" (103). For Whitman, the baseline of identity resides in atoms, and this means that his ubiquitous first-person singular is just as much itself when formed into grass (or anything else) as when formed into his person. That may ring a note of apprehension for readers who are more comfortable having names and faces. Atoms, in this sense, have a lot in common with grass: both are egalitarian, abundant and equal, but they hardly lend themselves to distinction and recognition; they are promising figures of mass population, but not of unique human portraits.

To indicate how this same representational impasse recurs regularly for 
Whitman beyond "Song of Myself," I would point to another 1855 poem, eventually titled "The Sleepers." Sleeping bodies share advantages for portraying egalitarianism with grass and atoms. Whitman writes of the sleepers, "I swear they are averaged now . . . . one is no better than the other" (75). We can imagine how sleeping people are indeed "averaged" and democratized compared to waking ones: their faces are relaxed; their unequal bank accounts do not buy them better or worse dreams; their personalities are temporarily uniform in stillness. However, in the next line Whitman confesses, "The night and sleep have likened them and restored them." Night and sleep have likened and restored them ... perhaps, but more likely night and sleep have obscured them. Sleepers may look alike, but precisely because they are not really their full individual selves in that state. Politically, if we extrapolate out to what a nation of sleeping bodies would be, the problem of taking them as a model of democratic collectivity becomes obvious. Sleepers may be average, democratic, and, as Whitman swears, "all beautiful," but they lack faculties and fall short of individual human personality (75).

Portraiture here provides a perspective that scholars otherwise tend to overlook as they affirm the democratic qualities of grass, atoms, and sleepers. Reynolds, for instance, remarks in Walt Whitman's America, "The valorization of the grass is a means of seeking resolution of the individual-versus-mass tension in nature itself: grass embodies simultaneously individualism, each spear a unique phenomenon, and radical democracy, as it is a common vegetation that sprouts everywhere, among all sections and races" (327). This is correct as far as it goes, but neglects the recognizability issue: each spear may be a "unique phenomenon," but it doesn't embody the kind of distinction we affirm for unique persons with their different faces and personalities. The point is nontrivial, because if Whitman cannot somewhere supply that deeper level of individuation, "Song of Myself" is not successful by his own standards of affording dignity and recognition to each reader, each citizen.

Some spiritual or universal self may survive the transmutations from grass to cow to human and back to grass again, but personality is not maintained through the process. In this sense, grass as a comprehensive (two-sided) mass-portrait (the leaf of grass is the individual, the field of grass is the mass) does not in itself supply a satisfactory integration of individual and collective, since it does not do justice to the individual side. Indeed, many critics have registered discomfort with Whitman's strategies for mediating the interplay of self to society through grass and other inhuman materials. Matthiessen early on summarized for many when he called Whitman's compromises here "tragic" (179), in the sense of 
sanctioning sacrifices and trade-offs at the expense of persons. On the other side of the mass-portrait, in terms of the field of grass representing the social body, we may reflect that after all, an undifferentiated field of grass translated into human terms may be a mob in the bad sense of a random destructive force, or a force compelled by a demagogue. Thus, there are several hazards in relying on grass and atoms to underwrite identity and collectivity in the mass-portrait. Whitman, as we noted and will see in more detail shortly, attempts to resolve these ticklish side effects of identifying with anonymous objects and processes by fusing the grass with his unique self-portrait.

Grass, atoms, and sleepers do unequivocally provide compelling, flexible poetic tropes. Lines like, "This grass is very dark to be from the white heads of old mothers, / Darker than the colorless beards of old men, / Dark to come from under the faint red roofs of mouths" (16) show the author making enduring music and images in a way that abstractions about population and politics could not match. In addition, Whitman deals with figures of the mass that are closer to the referent, namely when he writes about crowds, mobs, and masses. He uses crowds in part to represent concepts and values, typically while situating himself among the throng. Pollak describes the "visionary poet's uncanny ability to re-form himself as part of a crowd, whether that crowd be understood as an eternal religion, an eternal family, an eternal nation, or an eternal profession" (95-6). The observation finds confirmation in lines such as "A call in the midst of the crowd, / My own voice, orotund sweeping and final" (46). Whitman's universalizing seems to intend a twofold effect. One, it would ensure that the poetry of the crowd is not merely sensationalism or reckless embrace of damaging social impulses, what Whitman recognizes as "the fury of roused mobs" (18). Two, it would assign intellect and dignity to crowds, which otherwise may provoke defensive rejection, as in the reactions of Ralph Waldo Emerson and Edgar Allan Poe (see below), examples of which Whitman was keenly aware.

As for situating himself among the crowd, the move operates much as interweaving himself in the leaves of grass: it creates a blended portrait where his image contributes coherence and order to unruly elements, while the elements link him to larger forces. Placing himself amidst the crowd has an additional effect that does not apply to the grass. Whitman standing or walking in the crowd makes him one of us. If atoms hold grass-cow-and-human together, electricity, or what he would later call "the body electric," holds crowds together. Whitman's Socratic gambit is to stress that he is exactly like other members of the crowd except in that he knows he is exactly like everyone else; he registers the 
electric bond. He states in the Preface, "the others are as good as he [the poet], only he sees it and they do not" (v). By showing the reader that he, Whitman, is an equal member "Hurrying with the modern crowd, as eager and fickle as any" (37), and provoking the reader to recognize herself that way also, he will awaken everyone to this truth of "the divine average," the divine current pulsing through all. Whitman's crowd is a place of transmutation where fleshly bodies become awakened souls precisely by recognizing themselves as mutual fleshly bodies.

If crowds awakened to their own equality constitute a utopian vision, certain negative aspects of the mob bring to mind a threatening dystopia. The question of the mob as unenlightened horde of violent bodies haunts "Song of Myself" and democratic theory and portraiture more broadly. In a sense, the image of the mob is the antithesis of the democratic portrait. A mob is a disordered conglomeration of what should be distinct selves. Fear of the mob is a major concern of the nation's founders and of democratic theorists of all stripes. Two of Whitman's own main influences, Emerson and Poe, were aghast at the mob. One can see the anxiety betrayed by Emerson, for example, in an 1867 speech in which he admonishes, "We wish to put the ideal rules into practice, to offer liberty instead of chains . . . believing that it will not carry us to mobs, or back to kings again." "25 Emerson imagines mobs and kings as two sides of the same anti-democratic coin. Poe for his part posits democracy as a mistake, and mobs as evidence thereof. ${ }^{26}$ When confronted by public and literati opinion, Whitman believed he needed to demonstrate to his readers and literary interlocutors that grass, atoms, and crowds were something other than dangerous mob formations.

\section{The Portrait in Mass-Portrait}

Whitman's foremost strategy is to impose himself as the principle of order governing the would-be mob: his prophetic self-portrait will intervene to bend readers away from random violence and towards enlightened self-expression. In one anonymous review of Leaves of Grass perhaps written by Whitman himself, the potential audience is told that "its author is Walter Whitman, and the book is a reproduction of the author. His name is not on the frontispiece, but his portrait, half length, is. The contents of the book form a daguerreotype of his inner being, and the title page bears a representation of its physical tabernacle." ${ }^{27}$ The review suggests the text and frontispiece together form a complete portrait of the author. The author, in turn, forms a representative portrait of 
the nation. So the book represents Whitman (and vice-versa), and Whitman represents America (and vice-versa). This scheme may amount to "carrying us back to kings again," to aesthetic demagoguery, because it depends so heavily on the image of one individual. Such is the delicate balance of the mass-portrait.

The logic of the self-portrait imposing itself on the mass-portrait appears in lines such as, "This is the touch of my lips to yours. . . this is the murmur of yearning, / This is the far-off depth and height reflecting my own face, / This is the thoughtful merge of myself and the outlet again" (25). From the intimate (a kiss) to the distant (the "far-off depth" of a landscape painting), everything is interwoven with "myself." Matthiessen reports, "Emerson had reached his own position that 'there is properly no history, only biography', a position that Thoreau, in his confidence, carried to the point of saying, 'Biography, too, is liable to the same objection; it should be autobiography," (631). "Song of Myself" carries such reasoning to the extreme. Autobiography (the textual equivalent of self-portraiture) saturates every line, directly or indirectly. Peter Bellis assesses, "Not only is the poet's work foregrounded from the very start ('celebrate'), but he also functions as the poem's 'subject'-in not one but two different senses: its language emerges from his subjectivity, and he also serves as the poem's topic." 28 Wherever the mass is in "Song of Myself," there also is the self.

This brings us to the richly studied question of the precise nature and identity of the Whitmanian self or "I." While likely no one is crying out for a fresh set of conjectures on this subject, the pertinent note here is that the self is a self-portrait which emerges in dynamic tension between the "I" and the mass - it cannot be adequately grasped apart from the mass-portrait. This simple observation makes sense of many complicated claims about "Song of Myself" and identity. If such claims have one thing in common, it is an insistence on the paradoxical, contradictory, multiple nature of Whitman's "I." This stands to reason when we recognize the "I" is always implicated in the mass and vice-versa.

To develop and distinguish his socially embedded "I," Whitman draws heavily on photography. If, as Folsom asserts, "Photography . . . came to be one of the key tests for Whitman's theories" (Native Representations, 101), it also came to be one of the key building blocks of his democratic portraiture, featuring in both the mass-portrait and the portrait-series, although deployed in different ways for each. Whitman had been thinking and writing admiringly about nascent photographic potencies since at least 1846 when he published "A Visit to Plumbe's Gallery" in the Brooklyn Daily Eagle. As acknowledged in discourses about photography from this period, portrait photography can 
be leveraged towards either of two overlapping representational modes: a more traditional metaphorical aesthetic, where one figure represents a type of person or a group of persons; or, a metonymic snapshot aesthetic (though the term "snapshot" belongs to the 1890s), where the image escapes mere representation and stands as a part of social and material reality, even usurping the real status of the portrait subject.

A characteristic instance of the metaphoric discourse of photography is Mathew Brady's Gallery of Illustrious Americans (1850), where the portraitslithographs taken from daguerreotypes - of prominent men function much as a bust of Caesar or a painting of George Washington had previously, representing both the state and a class of persons. A characteristic instance of the metonymic discourse of photography is found in Oliver Wendell Holmes's essays on photography, where he associates photographs with sunlight and calls them "a mirror with a memory." 29 Both sun and mirror emphasize the material base of the photographic image. This metonymic discourse of photography has come, in contemporary scholarship, to be frequently associated with Charles Sanders Pierce's theory of indexicality, a mode of signification involving material continuity - such as the touch of sunlight on skin or, indeed, on exposed film. ${ }^{30}$ Additionally, note that both the metaphoric and metonymic discourses of photography participate more-or-less in what Dana Luciano identifies as the "longstanding belief in photographic objectivity and transparency, which positions the photographic image as an unmediated record of the world." 31

In "Song of Myself," Whitman uses both photographic potencies. His mass-portraits are more metaphorical. When he positions himself as standing for the mass, he draws on photographic metaphor. The portrait-series on the other hand is meant to be metonymic, with the catalogs capturing quick pictures from everyday life. When Whitman positions himself as a member of the crowd, he draws on the photographic metonym of actual physical presence. Combined, Whitman uses these two modes to make a claim for his self-portrait as transcendently true and materially real.

Nowhere is Whitman's claim to the physical and simultaneously transcendent authority of his self-portrait more pronounced than in his iconic 1855 frontispiece to Leaves of Grass. The British engraver Samuel Hollyer produced the image, taken from a daguerreotype by Gabriel Harrison. Hollyer's work has a layered effect, showing Whitman's bust area in detailed pseudo-photographic focus, then transitioning into a sketchy outline at the waist, and finally fading into the page at the thighs. Thus, the image combines photographic and painterly effects. Folsom identifies that Whitman "stands against the most demo- 
cratic of backgrounds, a vast blank page" (Native Representations, 145). This image, called "the street figure" by Whitman ( $W W C, 2: 412)$, was replaced as frontispiece in subsequent editions, in which Whitman employed frontispieces that represented him at approximately the age he was at the time of publication. Such temporal specificity made sense if Leaves of Grass was, as he promoted, "an attempt, from first to last, to put a Person, a human being (myself, in the latter half of the Nineteenth Century, in America) freely, fully and truly on record, my definitive cartes de visite to the coming generations of the New World" (LG 1881, p. 562). Whitman did retain the 1855 frontispiece elsewhere in later editions, where it was typically set opposite the first page of "Song of Myself," confirming that its primary referent in the book was this complex self-portrait of a poem. "The portrait in fact is involved as part of the poem," Whitman told William Sloane Kennedy. ${ }^{32}$

Much has been written about the 1855 frontispiece, especially its workingman, bodily quality in contrast to the cerebral, spiritualized heads of prior depictions of poets. The workingman effect places Whitman among the laboring masses, the crowd, whom he will detail in the catalogs. In other words, it sets him in the portrait-series and the logic of photographic metonymy-he stands among us, a part of the actual daily world, the divine average. At the same time, and even more assertively, the frontispiece deploys that other photographic logic of metaphor by which he stands for us, as his self-portrait stands for "Song of Myself" and Leaves of Grass. The question of how this single, specific image stands for each member of his readership invokes the most basic problem of democratic portraiture, namely, how to preserve distinction and equality in a single coherent image. Folsom describes how Whitman was often "looking for ways . . . single images added up to a totality." "33 Whitman's larger answer in "Song of Myself," as I have mentioned, is to balance the mass-portrait and portrait-series in an overarching democratic portrait, with himself as its emblem. That larger answer, however, does not resolve the specific question of the frontispiece and how it works. Trachtenberg details the way Whitman uses the frontispiece to comment on and redefine what Mathew Brady took to signify an "illustrious American" in his gallery, where pictures of economic and political elites reigned (69). Whitman's street figure stood against this aesthetic- political elite and aimed to liberate the mass from its tyranny. But he did not dissolve the representational tyranny altogether. The new "illustrious American" was not a businessman or politician; he was a poet; he was-Whitman. In this sense, the frontispiece might be Exhibit $\mathrm{A}$ in a case about the power and also intractable difficulties of democratic portraiture in general and Whitman's mass-portrait in particular. 
During the same period that Whitman was working on the first edition of Leaves of Grass, Søren Kierkegaard was worrying about the opposite pole of the photographic mass-portrait, the one that overemphasized equality to the point of sameness (instead of overemphasizing representativeness to the point of hierarchy). Kierkegaard mused, "With the daguerreotype, everyone will be able to have their own portrait taken - formerly it was only the prominent; and at the same time everything is being done to make us all look exactly the same- so that we shall only need one portrait" (quoted in Native Representations, 147). In Kierkegaard's thinking, we will "only need one portrait" for Susan Sontag's reason that "[i]n the open fields of American experience, as catalogued with passion by Whitman and as sized up with a shrug by Warhol, everybody is a celebrity ... no person is more interesting than any other person." 34 Translated into the problem of democratic portraiture, the problem of maintaining both equality and distinction, Kierkegaard and Sontag diagnose a swerve towards equality at the cost of distinction: we will "all look exactly the same"; "no person is more interesting than any other person." The former, Whitman would deny; the latter, he would embrace. Whitman's trouble is plain: what he wants to affirm and deny is the exact same thing - he wants it when it is called "equality" but not when it is called "sameness."

\section{The Portrait-Series}

Preparing to write Leaves of Grass, Whitman made a note to himself: "Poem of pictures. Each verse presenting a picture of some characteristic scene, event, group, or personage-old or new, other countries or our own country." 35 His plan to write a poem consisting of a series of portraits and scenes became what scholars know as the catalogs of "Song of Myself," which to some degree pervade the whole poem. Oliver Wendell Holmes, an acute reader of Whitman and of photography, recognized the use of photographic style in Whitman's catalog poetics, writing in 1891's Over the Teacups, "He accepts as poetical subjects all things alike, common and unclean, without discrimination, miscellaneous. . . . He carries the principle of republicanism through the whole world of created objects. He will 'thread a thread through [his] poems', he tells us, 'that no one thing in the universe is inferior to another thing"' (234). Whitman accepts everything in his sight without classifying or stratifying, like a camera capturing pieces of reality in the snapshot aesthetic of photography. This snapshot effect is a key hallmark of the portrait-series in "Song of Myself," along with coordinate syntax and paratactic accumulation of sentences. Together they support one 
pillar of Whitman's democratic portraiture.

I have described the mass-portrait as metaphoric and the portrait-series as metonymic. A related point is that the mass-portrait goes by a logic of identity ("I" am the mass), while the portrait-series goes by a logic of contiguity ("I," and this person, and this person, and this thing, and this thing ... ). For this reason, critics have noted the importance of "and" to the catalogs.

"The use of the conjunctive and . . . serves both to separate and link persons and objects in a single nonhierarchical plane," observes Erkkila; "The use and repletion of and is in effect a syntactic enactment of the principle of many and one" (98). The portrait-series represents persons, things, and world as democratically "linked," signifying and enacting linkage through the conjunction "and." Whitman uses "and" so consistently that it becomes an echoing presence in the poem even in its absence, so that we tend to hear it where there is only a comma on the page, punctuating an end stopped line in the catalogs. "And" is used primarily within lines, as a kind of internal rhyme:

Patriarchs sit at supper with sons and grandsons and great grandsons around them, In walls of adobe, in canvass tents, rest hunters and trappers after their day's sport.

The city sleeps and the country sleeps,

The living sleep for their time .... the dead sleep for their time,

The old husband sleeps by his wife and the young husband sleeps by his wife . .

Creating a rhythm and binding lines together, "and" is fundamental to the portrait-series' syntax and logic alike.

Working alongside "and" according to the same logic of contiguity, Whitman deploys paratactically listed sentences, where the order could be reshuffled with little change in meaning, where no sentence is subordinated to another. He reinforces this horizontal democratizing effect with parallelism and anaphora, so that a shifting set of words ("the," "where," "over," "upon," "at," "through," "pleas'd," "again") repeat five-to-forty times in a row at the beginning of lines in the way that "and" repeats within lines:

The pure contralto sings in the organloft,

The carpenter dresses his plank .... the tongue of his foreplane

whistles its wild ascending lisp,

The married and unmarried children ride home to their thanksgiving dinner,

The pilot seizes the king-pin, he heaves down with a strong arm,

The mate stands braced in the whaleboat, lance and harpoon are ready,

The duck-shooter walks by silent and cautious stretches,

The deacons are ordained with crossed hands at the altar,

The spinning-girl retreats and advances to the hum of the big wheel, 
The farmer stops by the bars of a Sunday and looks at the oats and rye,

The lunatic is carried at last to the asylum a confirmed case . . . (21)

The portrait-series, then, is marked syntactically by extensive coordination within lines and repetition of articles or prepositions at the opening of lines. Combined with end-stopped lines devoted to a single image and closing largely on commas, these constitute the grammar of the portrait-series. In "Song of Myself," the catalog passages highlight this paratactic grammar and logic, but it is used elsewhere and pervades the poem even outside of the long catalogs, so that its democratizing effect is always echoing for the reader. ${ }^{36}$

Beyond grammar, the portrait-series sections are structured by a certain photographic aesthetic. One might presume that if Whitman lived a thousand years, he would have kept expanding his portrait-series without limit, like a photo album with no last page. In Kierkegaard's critique and in other contemporary accounts such as Herman Melville's Pierre (1852), this everyone-has-their-daguerreotype-taken motif results in the oblivion of distinction. In "Song of Myself," because the theoretically limitless series of portraits is bracketed by the mass-portrait, the series carries a rationale and a purpose that preserves it from oblivionating digression: the many portraits are the vital legitimating content of the mass-portrait, bridging the gap between the abstraction of the mass and the narcissism of the "I." The portrait-series is the alphabet filling in between the alpha-and-omega totalization of the mass-portrait, supplying human scale and middle ground, a language beyond hyperbolic extremes. Context is everything here, for without the mass-portrait-if "Song of Myself" was made up only of catalogs - that would justify a reading of Whitman's democratic portraiture as a morass of unorganized fragments. In context, as if fulfilling the promise to "not have a single person slighted or left away" (25), the portrait-series is purposeful, preserving distinction and the independence of individuals within the collective.

In addition to what we have seen of the frontispiece, Whitman ties the portrait-series to the mass-portrait repeatedly and in various ways, bonding them as closely as possible, typically through his "I." At the end of the long catalog in what would become section 15, the speaker tells us, "And these one and all tend inward to me, and I tend outward to them, / And such as it is to be of these more or less I am" (23). In the second line, he summarizes the series of portraits by affirming he is one of them, a member of the crowd. But in the first line he also situates himself outside of the series and larger, with a gravitational force matching its own, so that a gravitational "tending" inward and outward connects them. In one instance, he is part of the portrait-series, in the other, part of the mass-portrait. "I" bridges the two. 
This overlapping "I" can make it tricky to recognize the mass-portrait and the portrait-series as distinct ways of thinking and representing political formation. Because Whitman uses himself as a figure in both, they seem to blur not just aesthetically but also conceptually. Larzer Ziff, for example, argues that Whitman "masters" the democratic paradox of individual and mass by "realizing it as a strong, seminal flow which diffuses a succession of sweet forms, rather than as a form itself, a structure forever threatened by the antagonism of its parts." ${ }^{37}$ Ziff takes "the succession of sweet forms" (the catalogs, the portrait-series) as the totality of Whitman's method, to the exclusion of structure (the mass-portrait). This kind of reading explains much about the conflicting critical accounts of "Song of Myself," such that one sometimes feels one is reading about different poems. Critics assume there is one method at work and they emphasize it, effectively subordinating and sometimes ignoring the other method, whether that is the "flow" of the series or the dominating structure of the mass-portrait. But the series of portraits in the catalogs are not part of the binary mass-portrait proposition contained in "One's-Self I sing, a simple separate person, / Yet utter the word Democratic, the word En-Masse," or vice-versa; these constitute distinct aesthetic-political images that are complementary to each other. In the mass-portrait, the "I" finds its characteristic position as the large-scale self-portrait frontispiece, holding the reader's attention as the representative illustrious American workingman. In the portrait-series, the "I" finds its characteristic position as the small-scale snapshot of Whitman among a crowd of other snapshots all flowing rapidly before the reader's attention, or as one image among many on the thickly stacked walls of New York's portrait galleries. ${ }^{38}$

Regarding the portrait-series in particular, a set of nineteenth-century debates around whether photography could be considered an art sheds light on ongoing debates about whether Whitman's catalog poetics could be considered good art. This strain of criticism was first taken up by the New Critics and others who found Whitman unfitted to their uses. The issues involved include specificity and selectivity. Folsom takes a line from the Preface, "He judges not as the judge judges but as the sun falling around a helpless thing" (v), to indicate the indulgent qualities of photographic imagination in the catalogs: "The lens and the light sensitive field were radically democratic; they absorbed what the light revealed" (Native Representations, 105). Whitman presents the portrait-series catalogs as if he were simply "absorbing what the light revealed" and recasting it in multiple rapid - but perhaps inadequately developed-images. Matthiessen, though rarely severely critical of Whitman, observes, "For the distinguishing gesture, the particular emphases of look and bearing that are the main preoc- 
cupation of the portrait painter, Whitman had no sustained gift, any more than he had for the detailed characterizations of the novelist" (612). The point is well taken as regards the portrait-series. Each snapshot was composed in a single long line, measurable in one breath per line, and did not afford time or space to fill in extensive detail. This brings us back to my larger point, however, that if the whole of "Song of Myself" consisted only of catalogs, many criticisms of the work would be more valid than they are. In fact, there is more to the poem than the one-line snapshots of the portrait-series. For example, would Matthiessen describe the frontispiece portrait as failing to convey a particular "look and bearing?"

Aside from detail, or lack thereof, the question in both photography and Whitman's portrait-series was selectivity. Could a practice that made no distinction between significant and insignificant objects be considered art? Painters, who had always specialized in selecting out the random to emphasize the meaningful, argued defensively that photography could never match them. Although Whitman appreciated painting, he sided with photographers in this dispute, on the grounds that photography was indeed nonselective and, precisely for that reason, democratic and desirable - an art to match the times, an art of the modern. If democratic art did not conform to aristocratic conventions of hierarchic selectivity, so much the better. I would argue that, indeed, photography and poetry do not necessarily lose artistic power by losing selectivity, nor does democratic portraiture - so long as counterbalancing formal features are in place to preclude mere randomness. And, whereas some critics complain about the lack of depth accorded each person in the series, the limited time onstage before the viewer's eyes in the catalogs may actually make each image more portrait-like, in the sense that portraits are single images of a person, not narrative digressions about a person.

Naturally, there are various accounts of the reason for Whitman's failure to linger in the portrait-series sections. Pollak, for example, finds its causes in the psychology of the author: "Whitman's style, with its nervous profusion of images, tends to move us away from any particular scene or gender or erotic desire before we have had a chance to examine it fully. . . . [T] he more highly individuated persona quickly escapes into the out of doors, where he finds a reason for being" (88-89). Rather than choosing an aesthetic-political intention, Whitman here acts out of compulsion, fleeing "thoughts and feelings he cannot endure" (Pollak, 91). Even if the causes are on some level psychological, I argue that the rapid, snapshot style movement of the portrait-series passages serves to efficiently produce a crowd within the poem, in part validating Whitman's 
claim to deliver democratic representation, and alleviating the tendency of his self-portrait to overpower with its representativeness.

Through the mass-portrait and the portrait-series, Whitman answers many of the questions regarding trees and grass with which we began. Despite its reputation, "Song of Myself" is really not a grasspoem but a grass-and-trees poem. Whitman combines and balances the order of the tree with the equality of the grass, while counteracting the hierarchy of the tree and the monotony and malleability of the grass. Drawing on the metaphoric and metonymic logics of photography, and developing a multivalent display of portrait-images, Whitman's formal innovations in combining mass-portrait and portrait-series in "Song of Myself" generate critical puzzles and account in part for the poem's enduring aesthetic-political resonance. Kathryn Walkiewicz, in "Portraits and Politics," has pointed out how later in his career Whitman used racialized portraiture "in an attempt to justify large-scale United states military invasions and genocidal projects." ${ }^{39}$ In 1855, he displayed no such intentions, but tried rather to offer portraiture in a fully egalitarian form.

However, as egalitarian as its intentions may be, and as impressive as is its imaginative scope, "Song of Myself" nonetheless fails to address certain serious problems when it comes to race and gender. While the analogy between portraits and plants is not perfect, thinking about grass and trees helps us see what Whitman's portrait formations can and cannot do in terms of picturing radically inclusive democracy. By folding in the portrait-series, Whitman's poetry is able to reimagine the grass as multi-hued instead of a uniform green, as if each leaf of the grass had a distinguishing individuality. Here, Whitman can fit himself in as one leaf among equals in a diverse field among all colors, shapes, sizes, and genders. The mass-portrait, on the other hand, is like a tree in which Whitman is the trunk and the masses are the leaves. The problem is plain: the leaves of the tree can be any combination of genders and races and colors and sizes Whitman wishes to enumerate, but the trunk is always white and male. ${ }^{40}$ This tells us something significant about the horizon of Whitman's universalism and the limits of the inclusivity of his democratic portraiture. In the frontispiece portrait, Whitman is a common workingman, "one of the roughs" (29), but one of the white roughs, a white workingman. His interweaving of mass-portrait and portrait-series may produce the effect of transcending class, but it does not produce the effect of transcending race and gender - at least in the seat of power. 


\section{Notes}

I am especially grateful to Abram Van Engen and Vivian Pollak for supporting this project.

1 A Thousand Plateaus: Capitalism and Schizophrenia. Translated by Brian Massumi (Minneapolis: University of Minnesota Press, 1987), 15.

2 David S. Reynolds, Beneath the American Renaissance: The Subversive Imagination in the Age of Emerson and Melville (New York: Oxford University Press, 1988); Betsy Erkkila, Whitman the Political Poet (New York: Oxford University Press, 1989).

3 In particular, scholarship in print and material culture has exploded over the past twenty years. I do not lean heavily into the material dimensions of portraiture in connection to Whitman's poetry, however, because the associated scholarship is little engaged with the conceptual and formational questions that are my focus.

4 Reynolds is representative in stating, "The famous opening lines of 'Song of Myself' immediately seek to resolve by fiat what had long been a basic problem in American life: how to balance the demands of the individual with those of the mass" (Walt Whitman's America [Vintage, 1996], 326).

5 With a few exceptions including Ed Folsom (in various works) and George Kateb ("Walt Whitman and the Culture of America," in A Political Companion to Walt Whitman, ed. John E. Seery [Lexington: University of Kentucky Press, 2011], 19-46), both of whom can safely be called Whitman enthusiasts as well as scholars, critics are skeptical about Whitman's ability to achieve balance, though they emphasize different ways in which he goes astray. Focusing on publishing and circulation, Matt Cohen describes how "Song of Myself" is finally more about Whitman making a celebrity of himself than anything else (Whitman's Drift: Imagining Literary Distribution [Iowa City: University of Iowa Press, 2017], 115). Jay Grossman finds the imbalance in Whitman rooted in the imbalance of the Constitutional settlement at the founding of the American nation, so that Whitman perpetually recapitulates within his lyric persona a destabilizing Federalist versus anti-Federalist debate (Reconstituting the American Renaissance: Emerson, Whitman, and the Politics of Representation. [Durham: Duke University Press, 2003], 15). Vivian Pollak psychologizes the issue, finding that "Whitman sought to democratize models of reading" but ended up reproducing "the quick loud word of the authoritarian father" (The Erotic Whitman [Berkeley: University of California Press, 2000], 86) - the push for collective equality eventuates in the return of postures of individual domination. F. O. Matthiessen cites the poet's tendency to "expand into the pride that annihilates all valid distinctions," destroying any harmony between self and community (The American Renaissance [New York: Oxford University Press, 1941], 548), and Quentin Anderson concurs that Whitman ends up subordinating everyone and everything to his overweening "I" (The Imperial Self: An Essay in American Literary and Cultural History [New York: Knopf, 1971]), while Pablo Neruda simply identifies in Whitman "the first totalitarian poet" (quoted in Walt Whitman's America, 49). Meanwhile, Wai-Chee Dimock claims the generalizing side of Whitman, his dependence on the "average" and on "kosmos," renders the work affectively dull and inhuman, closing off "access to a special world of loves and hates" - the abstract collective overpowers the real individual (Residues of Fustice: Literature, Law, Philosophy [Berkeley: University of California Press, 1996], 124). Similarly, Kerry Larson believes Whitman is too diffuse, failing to generate the coherence called for by "Song of Myself" and his larger poetic project (Whitman's Drama of Consensus [Chicago: University of Chicago Press, 1988]). David S. Reynolds argues Whitman recapitulates the contradiction between individual and collective without resolving it (Walt Whitman's America).

6 Core sources on photography in "Song of Myself" include Alan Trachtenberg's Reading American Photographs: Images as History, Mathew Brady to Walker Evans (New York: Farrar, Strauss, and Giroux, 1990), Folsom's Walt Whitman's Native Representations (New York: Cambridge University Press, 1994), and Reynolds's Walt Whitman's America. 
7 Folsom in Native Representations and Reynolds in Walt Whitman's America provide strong background on Whitman's overall visual cultural context. Marcy Dinius in The Camera and the Press: American Visual and Print Culture in the Age of the Daguerreotype (Philadelphia: University of Pennsylvania Press, 2012) and Sarah Blackwood in The Portrait's Subject: Inventing Inner Life in the Nineteenth-Century United States (Chapel Hill: University of North Carolina Press, 2019) describe, respectively, the material culture and psychological discourse that inform Whitman's visual culture.

8 See, for example, Douglass's "Lecture on Pictures" and "Pictures and Progress" (Picturing Frederick Douglass: An Illustrated Biography of the Nineteenth Century's Most Photographed American [New York: Norton, 2015], 126-141 and 160-173) and Melville's Pierre; or, The Ambiguities (New York: Harper and Brothers, 1852).

9 Portraits: A History (New York: Abrams, 2003), 15.

10 Likeness: A Conceptual History of Ancient Portraiture (Evanston, IL: Northwestern University Press, 1968), 4.

11 Quoted in Hans Belting, Face and Mask: A Double History, translated by Thomas S. Hansen and Abby J. Hansen (Princeton: Princeton University Press, 2017), 9.

12 Elsewhere, I develop a word and image approach to portraiture. Important studies of portraits and American literature, such as Susan S. Williams's Confounding Images: Photography and Portraiture in Antebellum American Fiction [Philadelphia: University of Pennsylvania Press, 1997], Dinius's The Camera and the Press, and Blackwood's The Portrait's Subject largely pass over art historical work on portraiture, in part because art history assumes visuality as the horizon of the genre. I claim there is value for the literary scholar in a background of art historical approaches to the portrait if they are leavened with image theory (particularly Hans Belting and Richard Brilliant) and word and image theory (particularly Gotthold Ephraim Lessing and W. J. T. Mitchell), so that they apply beyond pictorial representation. I also draw insights from John Klein's argument that the defining feature of the portrait is its social agency. In sum, I claim that a portrait is really an image held in the imagination (in fact the imagining-body) of a viewer/reader. This portrait-image may be generated by a visual or verbal depiction of a person, in other words a picture or a literary description. For Belting, see $A n$ Anthropology of Images: Picture, Medium, Body, translated by Thomas Dunlap (Princeton: Princeton University Press, 2014) and Face and Mask; for Brilliant, see My Laocoön: Alternative Claims in the Interpretation of Artworks (Berkeley: University of California Press, 2000) and Portraiture (Cambridge, MA: Harvard University Press, 1991); for Lessing, see Laocoön: An Essay on the Limits of Painting and Poetry, translated by Edward McCormick (Baltimore: Johns Hopkins University Press, 1984); for Mitchell, see Iconology: Image, Text, Ideology (Chicago: University of Chicago Press, 1987) and Picture Theory: Essays on Verbal and Visual Representation (Chicago: University of Chicago Press, 1994); for Klein, see "The Mask as Image and Strategy" (The Mirror and the Mask: Portraiture in the Age of Picasso, edited by Paloma Alarco and Malcolm Warner [New Haven: Yale University Press, 2007], 25- 35) and "The Social Agency of Portraiture" (Matisse Portraits [New Haven: Yale University Press, 2001], 1-15).

13 Unless otherwise noted, all citations come from the first edition of Leaves of Grass (Brooklyn, 1855), available on the Walt Whitman Archive (www.whitmanarchive.org).

14 For a cornerstone text on Whitman and rhetorical style, see C. Carroll Hollis's Language and Style in Leaves of Grass (Baton Rouge: Louisiana State University Press, 1983). As I uncover later in the essay, paratactic and hypotactic syntax relate to metonymic and metaphoric figuration, respectively. Hollis claims that Whitman's inventive pre-Civil War work was metonymic whereas his post-War output saw decline into metaphoric traditionalism (186). While not tracking changes of style across time, I differ from Hollis in reading in the 1855 Leaves a carefully constructed interplay of metonym and metaphor, parataxis and hypotaxis, rather than metonymic dominance. 
15 See Horace Traubel, With Walt Whitman in Camden, 1:367, available on the Walt Whitman Archive. Hereafter $W W C$.

16 Leviathan: Or the Matter, Forme and Power of a Commonwealth Ecclesiasticall and Civil (New York: Cambridge University Press, 1904), I.16.13.

17 See Lefort, "The Image and the Body of Totalitarianism" (in The Political Forms of Modern Society: Bureaucracy, Democracy, Totalitarianism, edited by David Thompson, [Cambridge, MA: MIT Press, 1986], 293-306) and Democracy and Political Theory, translated by David Macey (Cambridge, UK: Polity Press, 1988). Lefort addresses Hobbes's theory of the Sovereign directly, claiming that democracy is a "creative power capable of weakening, even slaying the totalitarian Leviathan" (21) through creative substitution in the "empty space" (Saul Newman, "The Place of Power in Political Discourse," International Political Science Review 25 [April 2004], 139-157) of power left in the wake of the collapse of theological foundations for political authority.

18 Whitman's insistence on The People as Sovereign is, in a larger sense, a feature of his discourse of equal rights. One primary strain of this discourse circulating in his antebellum world was an older enlightenment idea of identical natural political rights applying to each individual, whereby they were protected from intrusions against themselves and their property as they engaged in the competitive pursuit of private gain. Another, more recently developing discourse came from social democrats that extended the meaning of equality to denote a universal natural justice, a positive right that didn't just protect individuals from harm but dictated the establishment of material social and economic parity. Whitman affirmed both.

19 Beneath the American Renaissance, 107.

20 American Renaissance: Art and Expression in the Age of Emerson and Whitman (New York: Oxford University Press, 1941), 650.

21 Quoted in Larson, Imagining Equality in Nineteenth-Century American Literature (New York: Cambridge University Press, 2008), 81.

22 Walt Whitman: The Making of the Poet (New York: Basic Books, 1984), 252.

23 Ed Folsom and Christopher Merrill, Song of Myself: With a Complete Commentary (Iowa City: University of Iowa Press, 2016), 8.

24 Scenes of Nature, Signs of Men (Cambridge: Cambridge University Press, 1987), 78.

25 Quoted in Floyd Stovall, American Idealism (Norman: University of Oklahoma Press, 1943), 54.

26 For example, see Poe's “The Man of the Crowd" (1840). In The Politics of Crowds: An Alternative History of Sociology (New York: Cambridge University Press, 2012), Christian Borch contrasts this story with Leaves of Grass to show how Poe dramatizes the loss of the individual to the crowd while Whitman embraces the crowd's radical democracy (127-131).

27 “'Leaves of Grass'-An Extraordinary Book," The Brooklyn Daily Eagle (September 15, 1855), 2. Available on the Walt Whitman Archive, ID: anc.00012.

28 Writing Revolution: Aesthetics and Politics in Hawthorne, Whitman, and Thoreau (Athens: University of Georgia Press, 2003), 87.

29 "The Stereoscope and the Stereograph," in Soundings from the Atlantic (Boston: Ticknor and Fields, 1864), 124-165. Page 129. For more on Brady and Holmes, see especially Trachtenberg, 
Reading American Photographs, and Sean Ross Meehan, Mediating American Autobiography: Photography in Emerson, Thoreau, Douglass, and Whitman (Columbia: Missouri University Press, 2008).

30 For a review and reading of photography as indexicality, see Mary Anne Doane, "The Indexical and the Concept of Medium Specificity," Differences 18 (2007), 128-152.

31 “Touching Seeing," American Literary History 28 (2016), 140-150 (p. 140).

32 The Fight of a Book for the World (West Yarmouth, MA: Stonecroft Press, 1926), 248.

33 “'This Heart's Geography Map': The Photographs of Walt Whitman," available on the Walt Whitman Archive, ID: anc.00275.

34 On Photography (New York: Farrar, Straus, and Giroux, 1977), 28.

35 Available on the Walt Whitman Archive, ID: uva.00289.

36 The mass-portrait passages and the catalog passages in the poem are both adjacent and intermingled. There are sections where the mass-portrait predominates (section 1 for example) and sections where the portrait-series predominates (section 15 for example). There are also many sections incorporating elements of both in various proportions.

37 "Whitman and the Crowd," Critical Inquiry 10 (1984), 579-591 (p. 586).

38 The catalogs themselves would have probably been unimaginable for Whitman without inspiration from photography and the crowded galleries in which early photographic images were displayed. As James Dougherty summarizes, "Ed Folsom, Miles Orvell, Richard Rudisill . . . [and] Ruth Bohan find the picture gallery, with its crowded, intense, and various displays, a prototype of the pictorial catalogues in 'Song of Myself' and many later poems" ("Art and Daguerreotype Galleries," in Walt Whitman: An Encyclopedia, ed. Donald D. Kummings and J. R. LeMaster [New York: Garland Publishing, 1998], 26-726).

39 "Portraits and Politics: the Specter of Osceola in Leaves of Grass, "Walt Whitman Quarterly Review 25 (Winter, 2008), 108-115.

40 The issue is mirrored in Whitman's actual politics. He supported the Free Soil Party in the late 1840s and early 1850s; the party opposed the expansion of slavery-primarily to preserve the privileged status of white labor. And he spoke of women's equality but would not have endorsed or accepted an African American or woman president (even in 1855 during his most radical period, let alone after the Civil War). He championed, instead, the idea of a white working-class president. 